REVISTA DE GESTÃO E SECRETARIADO

MANAGEMENT AND ADMINISTRATIVE

PROFESSIONAL REVIEW

ISSN: 2178-9010
Revista GeSec

São Paulo, SP, Brasil

11(2), p. 211-234

maio/ago. 2020

DOI: http://dx.doi.org/10.7769/gesec.v11i2.1039

\title{
True heroines: unveiling the female management of startups' entrepreneurs
}

\author{
Verdadeiras heroínas: desvelando a gestão feminina de empreendedoras de \\ startups
}

\author{
Luiz Guilherme Rodrigues Antunes ${ }^{1}$ \\ Arlete Aparecida de Abreu $^{2}$ \\ Mayra Mendonça Rodrigues ${ }^{3}$
}

\section{Resumo}

The objective of the article is to identify traits or characteristics of the female management of startups' entrepreneurs. Thus, the study is characterized as qualitative, descriptive and multiple cases, in which data collection took place through semi-structured interviews with two entrepreneurs from Itajubá (MG) startups. The criteria of representativeness, availability and minimum working time were established for choosing the participants. The content analysis was carried out through the categories: female trajectory, leadership and barriers. The main results about female management are associated with the female trajectory, especially by childhood, family support and professional career; leadership characteristics of respect, equality, democracy and participation leading to transformational leadership; and challenges for the entrepreneurship practice such as discrimination, harassment and reconciliation between professional, personal and intimate life. The main contributions of the article are the leadership characteristics adopted by the respondents, which, even facing to past and current challenges, they manage based on respect, trust and mutual growth. The main originality of this paper is the analysis of female management based on the relations of the trajectories and leadership of women, as well as research in the field of entrepreneurial startups, an aspect not yet portrayed in the literature.

Palavras-chaves: Female management. Female Entrepreneurship. Women's Leadership. Startup.

\begin{abstract}
O objetivo do artigo é identificar o modelo de gestão feminina de empreendedoras de startups. Dessa forma, o estudo se caracteriza como qualitativo, descritivo e de múltiplos casos, em que a coleta de dados se deu por meio entrevistas semiestruturada com duas empreendedoras de startups da cidade de Itajubá (MG). Para escolha das sujeitas estabeleceu-se os critérios de representatividade, disponibilidade e tempo mínimo de atuação. Já a análise se deu por meio da análise de conteúdo por meio de categorias de trajetória feminina, liderança e barreiras. Os principais resultados sobre a gestão feminina estão associados com a trajetória feminina, especialmente pela infância, apoio familiar e percurso profissional; características de liderança de respeito, igualdade, democracia e participação acarretando a liderança transformacional; e desafios para a prática do empreendedorismo como discriminação, assédio e conciliação entre a vida profissional, pessoal e íntima. Como principais contribuições do artigo estão as características de liderança adotadas pelas pesquisadas, que, mesmo diante de desafios passados e atuais, gerenciam com base no respeito, na confiança e no crescimento mútuo. A principal originalidade do trabalho está na análise da gestão feminina pautados nas relações

\footnotetext{
${ }^{1}$ Doutorando em Administração na FEA/USP, Docente no Instituto Federal de Ciência, Educação e Tecnologia de Minas Gerais (IFMG).

${ }^{2}$ Doutora em Administração, Docente no IFMG.

${ }^{3}$ Graduanda em Administração no IFMG.
} 
das trajetórias e liderança das mulheres, bem como a investigação no campo de empreendedoras de startups, aspecto não retratado ainda na literatura.

Keywords: Gestão Feminina. Empreendedorismo Feminino. Liderança Feminina. Startup.

\section{Introduction}

The discussion about the role of women has gained notoriety since the last few decades, and has been mainly based on the struggle for her social insertion and participation in the business world (Baniski, Martins, Maier \& Steiner Neto, 2016). One of the objectives of this struggle is to change the "housewife" stereotype attributed to women with professional career prospects, especially in so-called male positions (Barbosa, Carvalho, Simões \& Teixeira, 2011).

The insertion of women in the job market is no longer just a financial complement, in the family sphere, but also the vocational exercise, based on professional training and personal fulfillment (Penãloza, Diógenes \& Sousa, 2008). At the same time, it has significantly contributed for economic growth and social welfare (Kelley, Baumer, Brush, Mahdavi \& Majbouri, 2017).

In the same sense, according to data from the Profile of Civil Society Organizations in Brazil, from the Institute of Applied Economic Research (IPEA), women have been the majority of people employed in organizations, however, they are still in social activities linked to their gender, such as the office assistant, nursing and similar positions, receptionists and other jobs (IPEA, 2018).

These data indicate that there is still a gap regarding the women occupation, especially in leadership positions (Owen, 2013). Likewise, when considering their performance as entrepreneurs, it is observed that this field is still under masculine domination (SánchesEscobedo, Díaz-Casero, Díaz-Aunión \& Heenández-Mogollón, 2014; Dieleo \& Pereiro, 2018; $\mathrm{Wu}$, Li \& Zhang, 2019); although women manage to create businesses in the same proportion as men, even in contexts of extreme difficulties (GEM, 2017).

Thus, in addition to understanding the traits or characteristics of female management, it is also beneficial to understand the leadership style of women, especially when considering that, in their business activities, they continue to be hampered by socially imposed barriers and restrictions (Wu, Li \& Zhang, 2019). Therefore, it is argued that due to gender difficulties, women's management and leadership have peculiar characteristics that interfere in their relations and in the organization in which they are inserted. For the purposes of this paper, the term gender is considered not only as a characteristic, but as the value system that 
divides people into different categories, in a non-overlapping way, even with the natural variability of particular characteristics (Hess \& Ferree, 1987, p.16).

Hence, the objective of this research is to identify traits or characteristics of the female management of startups' entrepreneurs. The specific objectives are: (i) to identify the trajectory of women until their arrival to the project; (ii) to identify the leadership style and characteristics of the entrepreneurs; and (iii) to present the barriers and limitations of performance.

This research is justified because it understands that female management and leadership is a theme that has constantly evolved, but stereotypes and a vision linked to male characteristics still prevail (Mukhtar, 2002; Hamilton, 2006; Millman \& Martin, 2007; Moller $\&$ Gomes, 2010), even if there is evolution about the subject, "little is known specifically about female entrepreneurship" (Aidis, Welter, Smallbone, \& Isakova, 2007, p. 158). Most studies have been published in North America, making it necessary to understand it in the context of developing countries (Sharif, 2018). Moreover, many researches are linked to large corporations, then, it is necessary to understand these variables also in small and medium companies and startups (Mukhtar, 2002).

Finally, in addition to this introduction, this paper presents four more sections. Thus, the next section addresses the theoretical framework based on female entrepreneurship, management and leadership. Subsequently, the research methods and procedures are described, presenting the characterization of the respondents. The third section presents the results, as well as the analyzes and discussions. Lastly, the final considerations are made followed by the references.

\section{Theoretical Framework}

The theoretical framework is divided into three parts, in which the first portrays the trajectory of women until the arrival of female entrepreneurship, the second part addresses female management and, finally, the last part portrays leadership.

\subsection{Trajectory: from home to female entrepreneurship}

For decades, women have struggled to gain more space in society, especially in the labor market. According to the Market and Unemployment survey, prepared by the InterUnion Department of Statistics and Socioeconomic Studies (DIEESE) carried out in 2017 and 
published in 2018, the presence of women in the labor market has been intensified over time, despite the reduction of these changes because of recent crisis. However, even over the years it is still necessary to review the situations faced by women, such as those related to the gender inequality, justified by a biological argument for a long time (Amorim \& Batista, 2012) and their difficulties in reconciliation between personal and professional life.

The sexist thinking, based on the belief that only women should be responsible for domestic work, was refuted by woman, allowing them to conquer more space in the labor market (Cappelle, Brito, Melo \& Vasconcelos, 2007). However, this event was marked by difficulties and obstacles, mainly in the primary and secondary sectors. Characteristics such as sensitivity, empathy, willingness to help and commitment (Amorim \& Batista, 2012) opened space for women to entrepreneur in the service sector. Though, in activities related to the industrial production process and its inputs, a certain resistance is perceived, which can also be extended to other spaces:

This resistance occurs both in the workplace and in the family, and needs to be gradually reduced or suppressed, as it is a process in constant movement, which involves the transformation of social representations and cultural aspects previously established (Cramer, Cappelle, Andrade, \& Brito, 2012, p. 66).

Only from the 1940s, the woman did subtly begin to extricate herself from the sexist culture, questioning her position, role, identity and her supposed fragility. However, they entered the job market with an almost exclusive role in the profession of primary teacher (Kanan, 2000); which, in turn, actually represents an extension of the woman's family role (Caetano \& Neves, 2011).

After the Second World War, numerous factors contributed to the emancipation of women and the creation of a new role in society. It has influenced women from all over the world through literature and cinema. A few years later, the patriarchal model began to show weaknesses, favoring so that women could enter the labor market in a more participatory way, even if they were unable to impose themselves as they wished (Couto, 2013).

In Brazil, the 1970s manifested the entry of women into the labor market more precisely (Amorim \& Batista, 2012). However, some research show that the movement of women from home towards this job market has created many problems and challenges: the reconciliation of multiple roles (Alperstedt, Ferreira \& Serafim, 2014); difficulties in accessing credit or financial difficulties in starting their business (Boden Jr. \& Nucci, 2000; Jonathan, 2003; Regina, 2005; Dutta \& Mallick, 2010; Field, Jayachandran, \& Pande, 2010).

Many of the elements, considered as the problems' originators faced by women in the labor market, represent an image of a historical institutional condition. Institutions, especially 
formal ones, do not only influence the limits for the development of female entrepreneurship, but also the types of companies in which women are engaged (Aidis et al., 2007). Discrimination against women and their potential is often the result of gender beliefs, which affects not only the probability of becoming an entrepreneur, but also the non-pecuniary benefits of these activities (Minniti \& Naudé, 2010).

\subsection{Female Management}

Studies have pointed out the lack of research on gender-related management characteristics, especially in small companies, and recent research on this topic still remains inconclusive (Mukhtar, 2002; Ahern \& Dittmar, 2012; Reinert, Florian \& Winnefeld, 2016).

Thus, most works on management do not present the separation between the male and female genders, attributing them the same characteristics. However, researchers have shown that individuals of different genders differ in behavior in certain socio-cultural contexts (Hofstede, 1998; Idris, 2008; Souza, Melo \& Oliveira, 2010). In the business field this is noticeable, especially when female leaders develop different organizational strategies and structures from their male counterparts (Mukhtar, 2002).

Regarding the characteristics of the female management model, some aspects can be pointed out in the international literature. The study by Rozier and Hersh-Cochran (1996) pointed out that female management has a more participatory style, as opposed to male. According to the authors, participatory management focuses on the participation of others in decision making. In addition to this characteristic, Mukhtar (2002) points out, based on other authors, some observable factors in women, which are: greater understanding, team building, interpersonal skills, democracy, communicability and negotiation of strategic partnerships. The study by Bear, Rahman and Post (2010) showed that female representation can improve the company's reputation and, consequently, strengthen the performance of companies through the positive association of the women image with customers. Finally, the study by Abdul Rashid (1995) showed that they are more educated in their social relationships, as well as they value interpersonal relationships, while men focus on controlling activities.

In the Brazilian context, Machado's research (2002) pointed out that women's management tends to be clearer and more widespread in the organization, aiming to satisfy those involved. Silveira and Gouvêa (2008) show that their decision-making process is more detailed and aims at the long term, in a participatory way. Finally, the investigation by Barbosa et al. (2011) studied the female management of entrepreneurs and reported that they 
were more respectful to others, showing themselves concerned with the quality of products and services and with customer satisfaction.

Finally, it is salutary to point out that the emergence of female management, especially the entrepreneurial one, is associated to the trajectory of women, as well as the barriers they have been suffering in their careers. In this way, evidence can be observed demonstrating that dissatisfaction within the organizational career is one of the factors that lead women to entrepreneurship (Mukhtar, 2002). Among the justifications for their dissatisfaction is the machismo rooted in the management hierarchies, which reflects in the gender structures of society, causing women to suffer resistance from men for professional advancement (Parkinson, Duncan \& Archer, 2017). In addition, the various invisible, but permanent, barriers to women's performance in the organizational and entrepreneurial field also contribute to this dissatisfaction (Diehl \& Dzubinski, 2016).

\subsection{Female Leadership}

The literature about leadership has shown that its definition is polysemic and difficult to construct because the term does not encompass all its representations (Ferreira \& Rodrigues, 2013). Nevertheless, it is widely accepted that leadership involves a behavioral process in which an individual seeks to influence other individuals or groups (Northhouse, 2012; Sharif, 2018).

Thus, the leadership study has covered different levels of organizational analysis such as individuals (micro), teams (meso) and organizations (macro) (Fonseca, Porto \& BorgesAndrade, 2015). Besides, other studies have pointed out that leadership is identified and clarified within personal, organizational and cultural contexts (Cole, 2005; Howell \& Costley, 2006); which, in other words, represents that the leader's behavior occurs through influences from the environment, values, personal aspects such as preferences, skills and experiences and by gender (Wang, Courtright \& Colbert, 2011; Guay, 2013).

Also, about leader's behaviors, Motta (2004) points out that the act of leading involves inter and intrapersonal skills such as self-knowledge, communication, expression and courage regard to future. Therefore, attitudes such as confidence, boldness and flexibility are required (Motta, 2004) for the most diverse situations. However, Cunha and Spanhol (2014) emphasize that the performance of leadership does not require rare skills, but skills that can be acquired through experiences and teachings. 
As for female leadership, it has shown particular skills and competences. Millman and Martin (2007) pointed out that, additionally to characteristics as confidence and motivation, women have developed the ability to reconcile and manage their home and work activities. Moreover, research by Ryan, Haslam, Morgenroth, Rink, Stoker and Peters (2016) and Parkinson et al. (2017) stated that women perform better than men in crisis and uncertainty situations.

Loden (1988), when observing some women in leadership conditions, managed to present some specific attributes of leadership, such as: (i) perception ability, which means understanding the others' situation, feelings or reactions, in addition to capturing non-verbal cues; (ii) the ability to listen, that is, patience and attention to what individuals say or ask, being able to encourage open discussions or allow them to conclude their thinking without interruption; (iii) feeling management, in which they are attuned to the feelings triggered in the environment, use them as a method of increasing communication and as a way of intergroup interaction; (iv) intimacy/authenticity, that means, the ability to develop a harmonious relationship, sharing experienced situations for encouragement, thus considering the individual as a whole and not just an employee; (v) positioning, which is the clear and direct position focusing on actions, using it to modify unwanted behaviors; and (vi) personal impact calculation, translated into the recognition of the impact of their leadership on individuals and how their position influences the construction of relationships.

The results of Sharif's study (2018) are related to transformational and transactional leadership. Thus, transformational leadership is associated to the ability of identifying and developing the subordinates' skills (Bass, 1998). This type of leadership is concerned about others, stimulating loyalty, respect, trust and motivation from employees to their leader. The leader's performance is based on advice, guidance, evaluation, facilitation and development of the team member (Rafferty \& Griffin, 2004; Bass \& Raggio, 2006). On the other hand, transactional leadership is involved with the practice of leadership guided by rules and norms, and based on authority (Caldwell \& Dixon, 2010); it is more focused on negotiating exchanges and punishments, if performance is lower than expectations (Avolio, Walumbwa \& Weber, 2009; Fonseca et al., 2015).

Hence, Sharif (2018) reports that the leaders that were studied in the Qatar Region presented predominantly transformational leadership, but in required situations they adapted to the transactional leadership style. Then, it is important to emphasize that, as the author explains, several other studies have pointed out that female leadership has a greater preponderance of being more oriented towards transformational, especially due to the 
characteristics of greater smoothness in management, showing themselves to be more understanding, intuitive, emotional, sensitive, sociable and receptive, among other characteristics, and for being concerned with satisfying needs (Mojza, Sonnentag \& Bornemann, 2011).

However, Mendell (1997) argues that female leadership is associated with the social construction of gender present since childhood. For the author, women's performance is related to the types of toys and style of interaction they obtained as children, since the games they played encouraged cooperation and the development of non-competitive skills, such as those provided by house games and dolls. In contrast, when using or not physical strength and imposing themselves more easily, boys were encouraged to competitive practices and reaching goals.

Finally, it is worth mentioning that the arrival of women to leadership is still rooted in expectations of preventing them from taking leadership positions (Owen, 2013). This fact is due to: (i) the spread of sexist practices that can be observed in organizational hierarchies, which reflect the structure of society, where women are underrepresented in executive positions, even though they have education, experience, qualifications and adaptations for leadership roles (Diehl \& Dzubinski, 2016); and (ii) reinforcement of women, when working in organizations dominated by men, in defending and legitimizing gender inequality in their organizations, leading to the "queen bee" phenomenon (Derks et al., 2016).

\section{Methods and Procedures}

In this study, its qualitative focus becomes evident, since the research is observed and elaborated in a social environment, in which it is part of a constructed reality, thus emerging the construction of knowledge based on the interpretive position, where the researcher and the respondent actively participate in the construction of knowledge (Golafshani, 2003; Ollaik \& Ziller, 2012). In addition, it is characterized as descriptive, since this type of research intends to describe and analyze, seeking to investigate the relations of a known phenomenon (Richardson, 1989).

As a research strategy, we used the study of multiple cases, as this research modality allows us to go beyond the individual analysis, by analyzing the presented cases. In this way, while the individual analyzes determine their own data, the analysis between the cases allows the identification of models, providing foundations for the creation of assumptions and the elaboration of theories (Branski, Franco \& Lima Junior, 2010). 
For data collection, interviews with startups managers were applied. The following criteria were used to select the respondents: (i) representativeness, since the interviewees should occupy a management position in the companies; (ii) availability, in which the interviewees should be willing to participate in the research; and (iii) have been working at least for five years in the management position. Thus, two entrepreneurs from different organizations were interviewed.

The interviews of just two women entrepreneurs are justified, considering the social and economic relevance of these women's enterprises. These entrepreneurs were pioneers in their respective cities in developing business in their areas (technologies for health and energy). Therefore, they needed to conquer their own spaces in these activities, since these were predominantly male. This characterizes the social relevance of those investigated, since the challenges to position themselves and obtain respect in the market required them to make greater efforts in business. Such factor differentiates them from other entrepreneurs, as it is considered that the latter, when entering these same markets, have already found an "open path" for the development of their enterprises. As an economic relevance, it was considered that their enterprises were successful, at the time of the interviews, mainly due to the factors of working time in the market, number of employees, professional achievement and, mostly, for being perceived as successful women by the other entrepreneurs in the city.

To conduct the interviews, a script was used, in which the questions were subdivided into five blocks: characterization of respondents and companies, childhood and family, professional training, characteristics of leadership and, finally, prejudice and feminism. The interviews were scheduled and conducted by videoconference. In its execution, the researchers explain the objectives of the research, answered any doubts, collected the free and informed consent form and requested the recording of the statements. Finally, the narratives were transcribed.

For data analysis, content analysis was used. According to Bardin (2016), content analysis is a set of techniques for assessing communications that seeks to systematically obtain the description of the content of the messages, allowing the inference of knowledge related to the conditions of production/reception of these messages. Therefore, three essential stages were developed, namely: pre-analysis, exploration of the material and treatment of the results obtained and their interpretation (Minayo, 2000).

In the first stage, the material was prepared and organized, read and coded. Subsequently, in the exploration and treatment stage, the most relevant parts of the narratives were located, according to the closed grid previously stipulated. Thus, the construction of the 
grid was based on some categories, such as female trajectory, leadership and barriers. Finally, the selected sections were analyzed. In the following topic, the results and discussions are presented.

\section{Results Analysis}

The collected data were divided into three categories, which are: female trajectory, leadership characteristics, challenges in the practice of entrepreneurship. In order to preserve the real name of the two respondents and, since the categorization of the interviews allowed the identification of important characteristics of each one, the interviewees were coded according to Figure 1:

\begin{tabular}{|c|c|c|c|c|c|c|}
\hline Code & $\begin{array}{c}\text { Company } \\
\text { Field }\end{array}$ & $\begin{array}{c}\text { Time of } \\
\text { management }\end{array}$ & Scholarity & Age & $\begin{array}{c}\text { Marital } \\
\text { status }\end{array}$ & Characteristics \\
\hline $\begin{array}{c}\text { Wonder } \\
\text { Woman }\end{array}$ & Energy & 8 years & $\begin{array}{c}\text { Doctorate } \\
\text { degree }\end{array}$ & $\begin{array}{c}33 \\
\text { years }\end{array}$ & Married & $\begin{array}{c}\text { Entrepreneur more } \\
\text { connected to the family } \\
\text { and the past and the } \\
\text { way they influence her } \\
\text { posture. Trust and } \\
\text { freedom are the } \\
\text { connectors between her } \\
\text { and employees. }\end{array}$ \\
\hline $\begin{array}{c}\text { Super } \\
\text { Girl }\end{array}$ & Health & 10 years & $\begin{array}{c}\text { Postgraduate } \\
\text { studies }\end{array}$ & $\begin{array}{c}45 \\
\text { years }\end{array}$ & Single & $\begin{array}{c}\text { Entrepreneur who } \\
\text { seeks equal relations, } \\
\text { respect and good } \\
\text { humor as a connector } \\
\text { between her and the } \\
\text { employees. }\end{array}$ \\
\hline
\end{tabular}

Figure 1. Characterization of Entrepreneurs

Source: prepared by the authors.

Each characteristic that allowed the categorization and subsequent coding of the entrepreneurs can be observed in the speeches and discussion held in each subsequent topic.

\subsection{Female trajectory: from home to the job market?}

Regarding the female trajectory, three subcategories could be identified: professional trajectory, family and childhood. Regarding the first, there are numerous obstacles faced by the entrepreneurs, especially in the beginning and in the search for independence: 
It can be seen that even with countless changes in society, sexist and patriarchal thinking still prevails. "... machismo still remarks relations between men and women today" (Santos, Neto, Caieiro, Versiani, \& Martins, 2016, p. 139).

[...] what I have felt throughout my professional life is that men have a little difficulty in being below women, in lower positions than women [...] [SUPER GIRL].

Women struggle against the devaluation of their work, the macho culture and prejudice; conquering space and fighting for equality (Silva \& Santos, 2018). In this respect, the role of the family, the freedom and trust established in these bonds makes all the difference:

[...] they supported me [my parents] in studying and doing what I liked, leaving me free for what I wanted to do and they didn't put their wishes above to me, encouraging me to create the company and this support is what influenced me to be courageous and to be able to develop what I have done so far [...] [WOMAN WONDERFUL].

Associated with family aspects, childhood can also prove to be a precursor to activities intended to creating an enterprise. Stimulating competitiveness, creativity and leadership can corroborate this process. For Ferreira and Nogueira (2013), entrepreneurship appears as a characteristic that is constituted in this phase.

I played more with boys than girls, but most games were street games, dodgeball, soccer, ball [...] and I was always competitive, I wanted to win every game, any game [...] [WONDER WOMAN].

However, it is clear that competition and the will to win (in childhood) was also related to the perception of the importance of collaboration and the concern for the collective.

[...] they were games that everyone could adapt and play together [...], that is, I looked for games where everyone could participate [WONDER WOMAN].

Therefore, the illustrative fragments point out that the competitive behaviors were also absorbed by the interviewees, contrary to what was exposed by Mendel (1997), that the female leadership usually does not have influences from the competitive activities from childhood. Below, more aspects about the leadership of the interviewees are presented.

\subsection{Entrepreneurial characteristics: how do women lead?}

Regarding the leadership way, respect and equality are central elements for the interviewees:

[...] I always treated people with a lot of respect, I never put myself as the owner of the company or as a boss [...] [SUPER GIRL]. 
At the same time, there is a strong concern with internal and external relationships, which is also confirmed by Jonathan (2003); Jonathan (2011). It is a more democratic and participative way of leading (Schiavani, Dias \& Oliveira, 2017), a transformational form of leadership (Alimo-Metcalfe, 2010).

[...] if I have an employee there, next to me, he already knows exactly what he needs to do, so, and I need to trust what he will deliver to me, and if someone doesn't know something for me it's not a problem, they need to be free to come and ask, ask for help [...] [WONDERFUL WOMAN].

[...] I always tried to treat everyone with a lot of respect, I never put myself as a leader or boss of the company, I ended up equaling myself to everyone and once they called my attention for that, but I always believed that. I believed that if I had to be on top pulling people, but equal, they would look at me with equality and I would be able to make it easier for them to talk to me [...] [SUPER GIRL].

Concomitantly with the managerial activity and the leadership role, women need to deal with several conflicts. This process requires them to balance reason and emotional intelligence; which is associated with the ability to discover, create and explore new opportunities (Rhee \& White, 2007) and also with the business performance (Oriarewo, Ofobruku \& Tor, 2019):

[...] I think I actually have more conflict with my husband than with my employees, because when we have to discuss something, we take it personally [...] [WONDERFUL WOMAN].

Aspects related to behavior and good mood can assist in this process. Positive attitudes and behaviors, as well as interpersonal relationships and satisfaction, are important elements for performance in the workplace (Oriarewo, Ofobruku \& Tor, 2019):

I always tried, in fact, to keep my mood. I always talked to people: 'Nobody works well if stressed'. So, my concern was that I was fine, but everyone was also fine [...] [SUPER GIRL].

In addition, the interviewees affirm that the feeling of equality, cooperation and trust are also essential for the good performance of the enterprise.

[...] I always believed that if I were in the lead, pulling the people more equally, they would look at me as an equal, having a good relationship and performance [...] [SUPER GIRL].

[...] if I have an employee with me, I need to trust what he needs to do, they need to be free to come and talk to me, I gave this freedom that my parents taught me to my employees [...]. [...] Being a leader means knowing how to work together with the team, rather than knowing how to command is knowing how to bring your team to you and make it develop in the best possible way with you. And trusting each other. [WONDER WOMAN].

As a consequence, it is possible to verify that leaders value the autonomy of employees, which results in a harmonious, pleasant and full of freedom and confidence work environment, characteristic of transformative leadership. 


\subsection{Challenges in the practice of female entrepreneurship: prejudice, sexism and harassment}

Finally, among the challenges faced by women in the daily practice of entrepreneurship, there is an emphasis on prejudice, also verified by Cramer et al., 2012, in addition to sexist attitudes and harassment. Situations that reveal these problems occur more indirectly, as can be seen:

[...] it never happened that he [former partner] had spoken directly, but I think that, indirectly, it happened a little [...]. In meetings, for example, when I was in charge of it, I felt that there was some discrimination from the partner when they realized that the person who would lead the discussions was a woman. [SUPER GIRL].

[...] he [former partner] thought I was there because I was the business owner's wife. [WONDER WOMAN].

Associated with the extreme negative attitude towards women is harassment, which according to Dias (2008) represents a form of violence and discrimination:

[...] at my first job, we always went with more discreet pants, and on a Friday, I went with jeans, because according to the other employees, on Friday it was a free day for clothes. And on this day, a gentleman, he taught me the service, he turned to me and said: 'You look better in jeans'. I was on my back, I didn't even turn around, I took a deep breath, I waited for him to get away, I called my boss and said I wanted to set up a meeting with him, in the presence of his wife, because with the presence of his wife the chances of the chief defends the man who harassed me were minors. But I reported what happened and quit the job [...] [SUPER GIRL].

Another recurring challenge is the reconciliation of professional, family and female life, as also pointed out by Cramer et al. (2012), Medeiros da Silva, El-Aouar, Pereira da Silva, Castro and Sousa (2019):

And I think it is very difficult to be a woman and reconcile all these things. So, nowadays I see in a very different way, a woman who has a company or who managed to entrepreneur in some way. Because it takes a lot of work to have a business, it takes a lot of work to entrepreneur. [WONDER WOMAN].

The reports still point out that despite the difficulties, the two interviewees feel fulfilled with their lives. Oliveira and Souza Neto (2010) point out that most entrepreneurs have a passion for what they do, which enhances the propensity to develop their own businesses.

\section{Discussions: understanding the female management of startup entrepreneurs}

When analyzing the female management of startup entrepreneurs, it was important to understand three aspects, which are: the trajectories of entrepreneurial women, the way they 
deal with their employees, that is, their leadership, and the challenges they had to overcome. Therefore, these factors lead to the understanding the female management as the managerial behavior of women entrepreneurs (Barbosa, Carvalho, Simões \& Teixeira, 2011) and are influenced by the respondents' cultural, social and historical contexts (Hofstede, 1998; Idris, 2008; Souza, Melo \& Oliveira, 2010).

Thus, data analysis reported that the management of the entrepreneurs was built on the values of their family, and these influenced the ways how startups are conducted. This becomes evident as the respondents report that the treatment with their subordinates is due to the freedom they obtained as children, resulting in a management style based on democracy and participation. Thus, according to Gomes (2004) and Oliveria, Souza and Neto (2010), female management has peculiar characteristics such as encouraging the participation of others, sharing information, sharing power, stimulating and valuing employees, as well as motivating them. In addition, understanding and communication (Mukhtar, 2002), satisfaction of those involved (Machado, 2002) and respect (Barbosa et al., 2011) are characteristics of the female management found in the literature and reinforced by this study.

Additionally, when considering that the management model is an institutional product surrounded by the beliefs and values of its leaders (in the case of managers) (Crozatti, 1998), it is clear that the way in which women entrepreneurs operate, that is, the management style, is a reflection of their professional experiences and trajectories. This finding is mainly based on the verification of the basic value of respect for others as a basis of women's performance, as also found in the work of Barbosa et al. (2011), even after having experienced practices such as harassment and sexism. Therefore, these results reaffirm the position of Santos et al. (2016, p. 139) in which “... machismo still remarks relations between men and women today”. Besides, discrimination and machismo against women are still invisible, but permanent barriers (Diehl \& Dzubinski, 2016), transcending labor relations and constituting historicalinstitutional conditions. In this same sense, there are sexist aspects in the reports about the difficulties of reconciling work, home and intimate life, as exposed by Alperstedt, Ferreira \& Serafim (2014).

Regarding the other analyzed aspect of female management, the leadership, it was found that they have characteristics such as equality, respect, democracy, participation, emotional balance and rationality, interpersonal relationships, humor, job satisfaction, trust, cooperation and freedom valuation. These characteristics are convergent with the studies developed by Motta (2004), Rafferty and Griffin (2004), Bass and Raggio (2006), Millman and Martin (2007) and Sharif (2018). It can also be observed that the female entrepreneurs 
possessed the skills of managing feelings, intimacy/authenticity, positioning and calculation of personal impact, as argued by Loden (1988).

Based on these characteristics, it is understood that the managerial style of the entrepreneurs can be framed as transformational. According to Bass (1998), Rafferty and Griffin (2004), Bass and Raggio (2006) and Sharif (2018), transformational leadership refers to the ability to identify and develop the skills of subordinates, aiming to stimulate values such as loyalty, respect, trust and motivation by leaders, through actions that provide advice, guidance, evaluation, facilitation and development of the team. Therefore, such aspects are perceived in the performance of the respondents.

At the same time, the challenges corroborate for some negative aspects in relation to management, as women, at times, find themselves hands-on regard to culturally solidified issues. In addition to these, aspects related to the management process (common to any type of business) are added; which somehow demands more from the female figure. According to Medeiros da Silva et al., (2019) competition, defaults, difficulty in obtaining capital and the trust of suppliers; reconciling business activities with family members; insecurity and prejudice for being a woman; are some of the adversities faced in entrepreneurial management.

The mishaps related to management are also confronted to ideas advocated about the social place of women; especially if they enter areas considered to be masculine; which impels them to try to hide some characteristics or weaknesses, being afraid to be judged as incapable for the business (Alperstedt, Ferreira \& Serafim, 2014). Generally speaking, it is important to emphasize the weight of the cultural aspect for the type of leadership performed by the entrepreneur, as this choice often implies that she must give up her personality or mix it to the expected, in order to enhance business.

Despite this, it is also important to mention that even with the macho culture being present in the trajectory of women and in the practices of entrepreneurship, this aspect does not influence the leadership style of these women. The role of the family and childhood revealed characteristics of women concerned with others, which leads to a leadership based on trust, respect and joint growth. It is important to note that, even in the face of problems related to the hierarchical position, experienced in their trajectory, female management in startups is not determined by these relationships. Finally, just as Sharif (2018) pointed out in its studies, in certain situations, managers also presented more transactional leaderships, especially in conditions where employees performed below the expected (penalties negotiation cases).

Revista de Gestão e Secretariado (GeSec), São Paulo, SP, 11(2), maio/ago., 2020, p. 211-234. 
No less than important, three major challenges were identified in the performance of women entrepreneurs, which are: discrimination regarding their gender; harassment; and reconciling the different worlds (work-home-intimacy). Thus, discrimination occurred in the same way as pointed out by Diehl and Dzubinski (2016), in which women, despite having education, experience and appropriate qualifications for leadership roles, are still underrepresented in executive roles. In this sense, Minniti and Naudé (2010) corroborate by showing that discrimination about women and their potential is often the result of gender beliefs, which affects not only the possibility of becoming an entrepreneur, but also the nonpecuniary benefits she could obtain from these activities. Regarding harassment, Freitas (2001) argues that, with the increase of women in the labor market, there was also an increase in their exposure to this conduct. Therefore, the same author points out that this attitude is rooted in customs based on male domination, as observed in a context marked by a dominant supremacy, as the entrepreneurship field. Finally, the conciliation of activities threatens the multiplicity of women's roles (Alperstedt, Ferreira, \& Serafim, 2014), mainly due to the overlapping of their various functions in their activities (professional, love and intimate), as reported by the respondents. In addition, the study by Arantes et al. (2018) with teachers also presented such results.

To conclude, five aspects can be raised by this research, they are: (i) children's games did not influence women's leadership, contrary to Mendell's (1997) approaches; (ii) there was not enough evidence to affirm that the dissatisfaction of these women with their career took them to the world of entrepreneurship, confirming the results of Mukhtar (2002); (iii) the results showed that women's experiences shaped the way they managed and led their subordinates, according to the research by Wang et al. (2011), Guay (2013) and Cunha and Spanhol (2014); however, this relationship was due to the inconvenience, that is, they avoided taking actions that they had suffered, especially those related to discrimination, machismo and harassment; (iv) although the study addresses two cases, it can be argued that there are still expectations to prevent the progress of women to leadership positions, corroborating Owen's (2013) findings; and (v) the reports did not present the "queen bee" phenomenon, described by Diehl and Dzubinski (2016), especially in cases where new female entrepreneurs emerged in male contexts. However, further research must be carried out in order to verify these aspects.

In summary, about the main findings of this study, it can be considered that the results indicate that female management values freedom and good relationships, seeking the development of employees' skills (Sharif, 2018).

Revista de Gestão e Secretariado (GeSec), São Paulo, SP, 11(2), maio/ago., 2020, p. 211-234. 


\section{Final considerations}

The purpose of this article was to identify the traits or characteristics of female management of startup entrepreneurs. The specific objectives sought to: (i) identify the trajectory of women until their arrival to entrepreneur; (ii) identify the leadership style and characteristics of the entrepreneurs; and (iii) present the barriers and limitations of performance.

The results indicate that the surveyed women entrepreneurs present a trajectory remarked by negative elements such as machismo and doubts about their ability to conduct business, counting on family support to overcome these phases. In addition, leadership and management seem to present its first traits in their childhood.

Another point that can be admitted is that even with all the difficulties revealed in the trajectory and others still experienced (discrimination, machismo and harassment); these women's way of conducting their business did not reflect fear, insecurity or some imposition. The leadership characteristics presented are based on postulates as trust and mutual growth, which gives even more relevance to the female posture in the entrepreneurial field nowadays.

The contributions of this research can be verified to the extent that it corroborates the discussions about the form of management and leadership, especially that related to women. The topic still needs to be consolidated in the literature and, therefore, such research helps to better understand this social phenomenon (Cassol, Silveira \& Hoelgebaum, 2007). Exposing the trajectory of these women also represents a social advance, as they still face countless challenges, fighting for more respect and representation, inside and outside organizations. As the most original contribution of the paper, it is possible to point out the analysis of female management based on the relation of the trajectory and leadership of women, as well as the investigation about female entrepreneurs of startups.

Finally, it is emphasized the difficulty of access to these women entrepreneurs, with the need to reapply this study to a greater number of representatives about the theme, as well as to cover other areas of women's performance, especially the literature counterpoint on the negative aspects of management. For future research, there is a need to further understand the relationship among women in this sector (since there was some evidence of support groups), to understand their existing relationships with their respective husbands within startups and to understand the more negative aspects of the way they manage and lead. 


\section{Referências}

Abdul Rashid, M. Z. (1995). A comparative study of successful male and female entrepreneurs in Malaysia. Malaysian Journal of Small and Medium Enterprises, 6, 1930.

Ahern, K.R., Dittmar, A. K. (2012). The changing of the boards: the impact on firm valuation of mandated female board representation. Quart. J. Econ. 127, 137-197.

Aidis, R., Welter, F., Smallbone, D., \& Isakova, N. (2007). Female entrepreneurship in transition economies: The case of Lithuania and Ukraine. Feminist Economics, 13(2), 157-183. https://doi.org/10.1080/13545700601184831

Alimo-Metcalfe, B. (2010). An investigation of female and male constructs of leadership and empowerment. Gender in Management: An International Journal, 25(8), 640-648. https://doi.org/10.1108/17542411011092309

Alperstedt, G. D., Ferreira, J. B., \& Serafim, M. C. (2014). Empreendedorismo Feminino: dificuldades relatadas em histórias de vida. Revista de Ciências Da Administração, 16(40), 221-234. https://doi.org/10.5007/2175-8077.2014v16n40p221

Amorim, R. O. \& Batista, L. E. (2012). Empreendedorismo Feminino: Razão Do Empreendimento. Pitágoras, 3(3), 1-13.

Arantes, I. C. S., Silva, M. A., Pereira, M. M. O. \& Antunes, L. G. R. (2018). Maternidade e Trabalho Docente: Desvelando as Concepções Discursivas de Professoras do Ensino Superior Público de Minas Gerais. Anais do Encontro de Ensino e Pesquisa em Administração e Contabilidade (ENAPq), Brasil, 6.

Avolio, B. J., Walumbwa, F. O., \& Weber, T. J. (2009). Leadership: current theories, research, and future directions. Annual Review of Psychology, 60, 421-449. doi: 10.1146/annurev.psych.60.110707.163621

Baniski, G. M., Martins, L. M., Maier, R. C., \& Neto, P. J. S. (2016). Mulheres empreendedoras: desvelando estratégias e perfil de gestão. Revista Espacios, 37 (37), 2016.

Barbosa, F. C., Carvalho, C. F., Simões, G. M. M. \& Teixeira, R. M. (2011). Empreendedorismo Feminino e Estilo de Gestão Feminina: Estudo de Casos Múltiplos com Empreendedoras na Cidade de Aracaju - Sergipe. Revista de Micro e Pequenas Empresas, 5 (2), 124-141.

Bardin, L. (2016). Análise de Conteúdo. Tradução Luís Antero Reto, Augusto Pinheiro. São Paulo: Edições 70. 
Bass, B.M. (1998), Transformational Leadership - Industrial, Military, and Educational Impact, Lawrence Erlbaum Associates, Mahwah, NJ.

Bear, S., Rahman, N. \& Post, C. (2010). The impact of board diversity and gender composition on corporate social responsibility and firm reputation. J. Bus. Ethics 97, $207-221$.

Branski, R. M., Franco, R. A. C. \& Lima Junior, O. F. (2010). Metodologia de estudo de casos aplicada à logística. Anais do Congresso de Pesquisa e Ensino em Transporte, Brasil, 24.

Boden Jr., R., \& Nucci, A. R. (2000). On the Survival Prospects of Men'S and Women'S New Business Ventures. Journal of Business Venturing, 15(4), 347-362.

Caetano, E. \& Neves, C. E. P. (2011). O universo feminino da sala de aula: O trabalho marcado pela questão de gênero. Revista Reflexão e Ação, Santa Cruz do Sul, 19 (1), 6077.

Caldwell, C. \& Dixon, R. (2010), Love, forgiveness and trust: critical values of the modern leader, Journal of Business Ethics, Vol. 93 No. 1, pp. 91-101.

Cappelle, M. C. A., de Brito, M. J., Melo, M. C. D. O. L., \& Vasconcelos, K. A. (2007). A produção científica sobre gênero nas organizações: uma meta-análise. Revista Eletrônica de Administração, 13(3), 502-528.

Cassol, N. K.; Silveira, A. \& Hoelebaum, M. (2007). Empreendedorismo Feminino: Análise da Produção Cientifica da Base de Dados do Instittute for Scientific Information (ISI), 1997-2006. Anais do Encontro da ANPAD, Rio de Janeiro, Brasil, 31.

Cole, G.A. (2005), Personnel and Human Resource Management, ELST Publishers, London, UK.

Couto, G. G. Mulheres Empreendedoras: perfil das mulheres à frente de micro e pequenas empresas no setor terciário. (2013). Monografia, Universidade Federal do Ceará, Fortaleza, CE, Brasil.

Cramer, L., Cappelle, M. C. A., Andrade, Á. L. S., \& Brito, M. J. de. (2012). Representações Femininas Da Ação Empreendedora: Uma Análise Da Trajetória Das Mulheres No Mundo Dos Negócios. REGEPE - Revista de Empreendedorismo e Gestão de Pequenas Empresas, 1(1), 53-71. https://doi.org/10.14211/regepe.v1i1.14

Crozatti, J. (1998). Modelo de gestão e cultura organizacional: conceitos e interações. Caderno de estudos, (18), 01-20.

Cunha, A. C. C., \& Spanhol, C. I. D. (2014). Liderança feminina: características e importância à identidade da mulher Female leadership: characteristics and importance to Revista de Gestão e Secretariado (GeSec), São Paulo, SP, 11(2), maio/ago., 2020, p. 211-234. 
woman's identity. Saber Humano: Revista Científica da Faculdade Antonio Meneghetti, 4(5), 91-114.

Dias, I. (2008). Violência Contra as Mulheres no Trabalho: O caso do assédio sexual. Sociologia, Problemas e Práticas, 57, 11-23.

Diehl, A.B. \& Dzubinski, L.M. (2016), Making the invisible visible: a cross-sector analysis of gender-based leadership barriers, Human Resource Development Quarterly, 27 (2), 181206.

Dileo, I., \& Pereiro, T. G. (2018). Assessing the impact of individual and context factors on the entrepreneurial process. A cross-country multilevel approach. International Entrepreneurship \& Management Journal, https://doi.org/10.1007/s11365-018-0528-1.

Dutta, N., \& Mallick, S. (2010). Enabling Women Entrepreneurs: Exploring Factors That Mitigate the Negative Impact of Fertility Rates on Female Entrepreneurship. Kyklos, 71(3), 402-432. https://doi.org/10.1111/kykl.12175

Ferreira, J. M., \& Nogueira, E. E. S. (2013). Mulheres e suas histórias: razão, sensibilidade e subjetividade no empreendedorismo feminino. Revista de Administração Contemporânea, 17(4), 398-417. https://doi.org/10.1590/s1415-65552013000400002

Ferreira, M. C. \& Rodrigues, A. O. M, L. (2013). O Fenômeno da Liderança: Uma Revisão das Principais Teorias. Fragmentos de Cultura, 23 (3), 1-15.

Field, E., Jayachandran, S., \& Pande, R. (2010). Do Traditional Institutions Constrain Female Entrepreneurship? A Field Experiment on Business Training in India. American Economic Review, 100(2), 125-129.

Fonseca, A. M. O., Porto, J. B., \& Borges-Andrade, J. E. (2015). Liderança: um retrato da produção científica brasileira. Revista de Administração Contemporânea, 19(3), 290-310.

Freitas, M. E. D. (2001). Assédio moral e assédio sexual: faces do poder perverso nas organizações. Revista de administração de Empresas, 41(2), 8-19.

Global Entrepreneurship Monitor (GEM). Empreendedorismo no Brasil - 2016. Simara Maria de Souza Silveira Greco (Coord.). Curitiba: IBQP, 2017. Disponível em < http://www.sebrae.com.br > Acessado em 08 de setembro de 2018.

Golafshani, N. (2003). Understanding reliability and validity in qualitative research. The Qualitative Report, (4), 597-606.

Guay, R.P. (2013), The relationship between leader fit and transformational leadership, Journal of Managerial Psychology, 28 (1), 55-73. 
Hamilton, E.E. (2006), Whose story is it anyway? Narrative accounts of the role of women in founding and establishing family businesses, International Small Business Journal, 24(3), 253-71.

Hess, B. B. \& Ferree, M. M. (1987). Analyzing Gender: A Handbook of Social Science Research, Sage Publications Inc., California, U.S.A.

Hofstede, G. (Ed.) (1998). Masculinity and Femininity: The Taboo Dimension of National Cultures. Thousand Oaks: Sage.

Howell, J. \& Costley, D. (2006), Understanding Behaviours for Effective Leadership, Pearson Prentice Hall, Upper Sadle River, NJ.

Idris, A. (2008). A profile of innovative women entrepreneurs. International Business Research, 1(2), 3-10.

Instituto de Pesquisa Econômica Aplicada (IPEA). Perfil das Organizações da Sociedade Civil no Brasil. Felix Garcia Lopez (Org.). (2018) Brasília: Ipea. Disponível em $<$ http://www.ipea.gov.br > Acessado em 08 de setembro de 2018.

Jonathan, E. G. (2003). Empreendedorismo feminino no setor tecnológico brasileiro: dificuldades e tendências. Anais do Encontro de Empreendedorismo e Gestão de Pequenas Empresas, Brasil, 3.

Jonathan, E. G. (2011). Mulheres empreendedoras: o desafio da escolha do empreendedorismo e o exercício do poder. Psicologia Clínica, 23(1), 65-85. https://doi.org/10.1590/s0103-56652011000100005

Kanan, L. A. (2000). Mulher e poder: um estudo sobre as práticas de liderança nos altos escalões das organizações de grande porte da indústria têxtil de Santa Catarina. Dissertação de Mestrado, Universidade Federal de Santa Catarina, Florianópolis, Brasil.

Kelley, D. J., Baumer, B. S., Brush, C., Green, P. G., Mahdavi, M. \& Majbouri, M., (2017). Global entrepreneurship monitor 2016/2017 report on Women's entrepreneurship. Babson College, Smith College and the Global Entrepreneurship Research Association.

Loden, M. (1998). Liderança feminina: como ter sucesso nos negócios sendo você mesma. São Bernardo do Campo, SP: Bandeirante.

Machado, H. (2002). Identidade de mulheres empreendedoras no Paraná. Florianópolis: Universidade Federal de Santa Catarina.

Medeiros da Silva, P. M., El-Aouar, W. A., Silva, A. W. P., Castro, A. Ram B. C., Sousa, J. \& Iana C. (2019). A Resiliência no Empreendedorismo Feminino. Revista Eletrônica Gestão \& Soc Iedade, 13(34), 2629-2649.

Mendell, A. (1997). Como os Homens Pensam. Rio de Janeiro: Rosa dos Tempos. 
Millman, C., \& Martin, L. M. (2007). Exploring small copreneurial food companies; female leadership perspectives. Women in Management Review, 22(3), 232-239.

Minniti, M., \& Naudé, W. (2010). What do we know about the patterns and determinants of female entrepreneurship across Countries? European Journal of Development Research, 22(3), 277-293. https://doi.org/10.1057/ejdr.2010.17

Minayo, M. C. S. (2000). O desafio do conhecimento: pesquisa qualitativa em saúde. 7. ed. São Paulo: Hucitec, 269 p.

Mojza, E.J., Sonnentag, S. \& Bornemann, C. (2011), Volunteer work as a valuable leisuretime activity: a day-level study on volunteer work, non-work experiences and well-being at work, Journal of Occupational and Organizational Psychology, 84 (1), 123-152.

Motta, P. R. (2004). Gestão contemporânea: a ciência e a arte de ser dirigente. Rio de Janeiro: Record.

Mukhtar, S. M. (2002). Differences in male and female management characteristics: a study of owner-manager businesses. Small Business Economics, 18(4), 289-310.

Northouse, P.G. (2012), Leadership Theory and Practice, 6th ed., Sage, Thousand Oaks, CA.

Ollaik, L. G. \& Ziller, H. M. (2012). Concepções de validade em pesquisas qualitativas. Educação e Pesquisa, 38(1), 229-241.

Oliveira, P. G.; \& Souza Neto, B. (2010). Empreendedorismo e Gestão Feminina: Uma Análise do Estilo Gerencial de Mulheres Empreendedoras no Município de São João delRei, Minas Gerais. Anais do Encontro de Estudos Organizacionais da ANPAD, Florianópolis, SC, Brasil, 6.

Oriarewo, G. O., Ofobruku, S. A., \& Tor, Z. A. (2019). The Implications of Emotional Intelligence on Entrepreneurial Performance: A Discuss. South Asian Journal of Social Studies and Economics, 3(1), 1-13. https://doi.org/10.9734/sajsse/2019/v3i130093

Owen, C. (2013). Gendered communication and public safety: women, men and incident management, Australian Journal of Emergency Management, 28 (2), 3-10.

Parkinson, D., Duncan, A. \& Archer, F. (2019) Barriers and enablers to women in fire and emergency leadership roles, Gender in Management: An International Journal, https://doi.org/10.1108/GM-07-2017-0090

Peñaloza, V., Diógenes, C. G., \& Sousa, S. J. A. (2008). Escolhas Profissional no Curso de Administração: Tendências Empreendedoras e Gênero. Revista de Administração Mackenzie - RAM, 9 (8) Edição Especial, 151-167.

Rafferty, A.E. \& Griffin, M.A. (2004), Dimensions of transformational leadership: conceptual and empirical extensions, The Leadership Quarterly, 15 (3), 329-354.

Revista de Gestão e Secretariado (GeSec), São Paulo, SP, 11(2), maio/ago., 2020, p. 211-234. 
Raes, E., Decuyper, S., Lismont, B., Van den Bossche, P., Kyndt, E., Demeyere, S. \& Dochy, F. (2013), Facilitating team learning through transformational leadership, Instructional Science, 41 (2), 287-305.

Regina, S. C. L. (2005). Desafios do Empreeendorismo Feminino: Uma reflexão sobre as dificuldades das mulheres pobres na condução de projetos geradores de renda. Revista Estação Científica, 1-7.

Reinert, R. M., Weigert, F., \& Winnefeld, C. H. (2016). Does female management influence firm performance? Evidence from Luxembourg banks. Financial Markets and Portfolio Management, 30(2), 113-136.

Richardson, R. J. (1989). Pesquisa social: métodos e técnicas. São Paulo: Atlas.

Rozier, C. K., \& Hersh-Cochran, M. S. (1996). Gender differences in managerial characteristics in a female-dominated health profession. The Health care supervisor, 14(4), 57-70.

Ryan, M.K., Haslam, S.A., Morgenroth, T., Rink, F., Stoker, J. \& Peters, K. (2016), Getting on top of the glass cliff: reviewing a decade of evidence, explanations, and impact, The Leadership Quarterly, 27 (3), 446-455.

Sánchez-Escobedo, M. D., Díaz-Casero, J. C., Díaz-Aunión, A. M., \& Hernández-Mogollón, R. (2014). Gender analysis of entrepreneurial intentions as a function of economic development across three groups of countries. International Entrepreneurship \& Management Journal, 10(4), 747-765.

Santos, C. M. M., Neto, A. C., Caieiro, M., Versiani, F., \& Martins, M. G. (2016). Are Women Breaking the Three Glass Walls? a Study With. E\&G Economia e Gestão, 16(45), 126-149.

Silva, D. I. S, \& Santos, P. J. (2018). Mulheres e o empreendedorismo feminino na microrregião de patos de Minas - MG. Cadernos de Gestão e Empreendedorismo, 6(2), 22-37. https://doi.org/10.32888/cge.v6i2.12766

Silveira, A., \& Gouvêa, A. B. C. T. (2008). Empreendedorismo feminino: mulheres gerentes de empresas. Revista de Administração FACES Journal, 7(3).

Sharif, K. (2018). Transformational leadership behaviours of women in a socially dynamic environment. International Journal of Organizational Analysis. https://doi.org/10.1108/IJOA-12-2018-1611

Souza, R., Melo, M., \& Oliveira, M. (2008). Empreendedorismo na perspectiva das relações de gênero: perfil, características, desafios e satisfação de empreendedores de empresas de base tecnológica de Belo Horizonte. Anais do Seminários em Administração da Revista de Gestão e Secretariado (GeSec), São Paulo, SP, 11(2), maio/ago., 2020, p. 211-234. 
Faculdade de Economia, Administração e Contabilidade da Universidade de São Paulo, São Paulo.

Schiavani, C. V., Dias, T. D. O. S., \& Oliveira, E. C. De. (2017). Elas no Comando: A Percepção de Colaboradores sobre a Liderança Exercida por Mulheres. Revista Conbrad, 2(1), 141-160.

Wang, G., Oh, I., Courtright, S.H. \& Colbert, A.E. (2011), Transformational leadership and performance across criteria and levels: a Meta-analytic review of 25 years of research, Group and Organization Management, 36 (2), 223-270.

Wu, J., Li, Y., \& Zhang, D. (2019). Identifying women's entrepreneurial barriers and empowering female entrepreneurship worldwide: a fuzzy-set QCA approach. International Entrepreneurship and Management Journal, 1-24.

Submetido em: 24.11.2019

Aceito em: $\quad 26.04 .2020$ 